\title{
Identification of the SNPs in MyoD Gene and Their Associations in Pakistani Indegeneous Cattle's
}

\author{
Javed A. Ujan, Abdul M. Shaikh, Abdul W. Jatoi, and Miandad Zardari
}

\begin{abstract}
The present research was aimed at presenting a genetic analysis of the associations between single nucleotide polymorphisms of MYOD1 and meat quality traits in commercial lines of Pakistani cattle breeds. The breeds were Red Sindhi cattle (RS), Thari cattle (TR), Sahiwali cattle (SW), Bhagnari cattle $(\mathrm{BN})$ and Cholistani cattle $(\mathrm{Cl})$. The results of the Allelic frequencies and Polymorphism Information Content showed a medium diversity. Least Square analysis for the novel mutation c.679G $>A$ is significantly associated $(P>0.05)$ with Back fat thickness (BFT) and Marbling (MB) but did not show a significant association with other traits such as Eye muscle area (EMA), Water holding Capacity (WHC), and meat tenderness (MT). Animal Geneticians and breeders consider both of these traits as the key traits for determining the meat quality in animals. This research will be helpful to furthermore improve the meat quality in Pakistani cattle breeds by using the marker assisted technology.
\end{abstract}

Index Terms - Calf breeding, SNP, meat quality, associations.

\section{INTRODUCTION}

Meat quality traits are related to the biological traits of the live animals, hence biological sciences, including genetics, physiology, cell biology, and biochemistry have been widely employed for decades to identify the biological mechanisms behind meat quality traits, like tenderness and water holding capacity of meat, but also with special attention on muscle growth, development and carcass composition. It is clear that meat quality traits are complex and multigenic in nature, hence detailed characterization would benefit from experimental approaches and technologies aimed at analyses of various genes and proteins which are influenced by several factors, such as breed, genotype, feeding, fasting, pre-slaughter handling, stunning, slaughter methods, chilling and storage conditions [1]. For the genetic basis, the correct selection of breeds is necessary because the genetic influence on meat quality is very different among breeds as well as among animals in the same breed. Such strong selection, especially in recent centuries, has resulted in the accumulation of new mutations with favorable phenotypic effects [2]. These new mutations can provide greater options, especially in

Manuscript received March 17, 2014; revised June 10, 2014. This work was supported by the Higher Education Commission, (HEC), Pakistan under Grant No: PM-IPFP/HRD/HEC/2012/3560 (sponsor and financial support acknowledgment goes here).

J. A. Ujan and A. M. Shaikh are with the Department of Zoology, Shah Abdul Latif Uiversity, Khairpur (e-mail: javed.ujan@salu.edu.pk, amanan.shaikh@salu.edu.pk).

A. W. Shaikh is with the Department of Chemistry, Shah Abdul Latif Uiversity, Khairpur (e-mail: wahid.jatoi@salu.edu.pk).

Minadad Zardari is the with Department of Microbiology, Shah Abdul Latif University, Khairpur (e-mail: pvc.salu@ salu.edu.pk). molecular technology. Many factors affect the quality of meat, including the way animals are fed, managed, slaughtered as well as both carcass handling and processing post-slaughter. While there is often emphasis on the management systems that can be implemented to meet market specifications, there has, until recent years, been little emphasis on factoring in the molecular or biological components of meat quality. Since last has few decades, advancement in molecular genetics have led to the identification of multiple genes or genetic markers associated with genes that affect traits of interest in livestock animals, including single genes of large effect and quantitative trait loci (QTL; genomic regions that affect quantitative traits). Intrinsic quality of beef, especially its tenderness, depend on post-mortem factors associated with meat ageing and muscle characteristics of live animals, which themselves depends on genetic and environmental factors. By the help of functional genomics approach to understanding the molecular basis of meat quality, we can gain further insight into the complex interplay of gene expression events involved in the development of meat quality. At present, genome projects have advanced our understanding of gene expression and helped elucidate the function of large portions of the genome.

Genetic selection for meliorated wellness and longevity is a major goal of dairy cattle breeders. Difference in meat quality is probably due to the variation in different genetic and environmental factors, which interact and ascertain the course of metabolic reactions in muscular tissue and also in the autopsy transition of muscle into meat. A candidate gene access may furnish a more channelized apprehension of the genetic basis for the manifestation of quantitative divergences among individuals [3]. The MyoD 1 gene is a member of the MyoD gene family. Myogenesis, a complex process involved in muscle fiber formation throughout embryonic development, differentiation and maturation [4]-[6] is completely controlled by the MyoD gene family. MyoD1 and MYF5 were believed to be candidate genes for meat production and meat quality [7], [8].

In previous studies, polymorphism in MyoD gene family and their association with carcass, meat quality, and reproduction traits in different pig lines and breeds has been reported [5]-[12]. Furthermore, Polymorphism in MyoD gene family and their effects on growth and carcass traits in Korean cattle, Han Woo, has also been reported [13]. Yet, to our best knowledge, very little research has reported on the relationship between the polymorphism of MyoD1 gene and meat quality traits in cattle. Therefore, objectives of this study were aimed at investigating the new Single Nucleotide polymorphism (SNP) in MyoD1 gene, to evaluate whether this polymorphism affected meat quality traits in 380 samples 
of Sindhi cattle breeds, and to estimate the allelic frequencies of five Sindhi indigenous cattle breeds, namely Red Sindhi cattle (RS), Thari cattle (TR), Sahiwali cattle (SW), Bhagnari cattle $(\mathrm{BN})$ and Cholistani cattle $(\mathrm{Cl})$.

\section{MAterials AND Methods}

\section{A. Data}

A total of 380 animals from five different cattle breeds, including Red Sindhi cattle (RS $n=63$ ), Thari cattle (TR $n=125$ ), Sahiwali cattle (SW $n=67)$, (QC $n=267$ ) and Bhagnari (XN $n=129$ ), each 2 years of age were used in this study. Blood samples of different cattle breeds were taken from the various breeding farms of Sukkur division. Red Sindhi cattle samples were collected from Ghousala Gambat, District Khairpur. The Thari cattle samples were obtained from Mubeen Ahmed Phulpoto Cattle farm, Wisryo Wahn, Thehri bypass, Khairpur Mir's, Sahiwali samples were taken from Naheed Qazi Cattle Farm, Taluka Rohri, District Sukkur farm of Sukkur and Bhagnari were from Village Rasool Bux Ujan Gambat,district Khairpur. All breeding populations of cattle's were used to analyze the allelic frequencies, genotypic frequencies, Hardy-Weinbeg Equilibrium and Polymorphism Information Content (PIC), and Gene Heterozygosity (He). Moreover, the marker assisted association of Single Nucleotide Polymorphism with the meat quality traits in Pakistani cattle breeds in MyoD1 gene was also identified.

\section{B. DNA Extraction and PCR Amplification}

Three hundred and eighty blood samples were taken from five Pakistani indigenous cattle breeds. DNA samples were extracted from leucocytes and isolated from Acid Citrate Dextrose (ACD) blood samples (ACD: blood is 1:6), treated with $2 \%$ heparin, and stored at $-80 \mathrm{C}$, following standard procedures [14]. Four primer pairs were designed based on NCBI database, according to the sequence of bovine MyoD1 gene (Gene bank accession number NC_007313.3) to amplify both exon and intron regions in MyoD1 gene using the "MEGA 5.2 software. Detailed information for Oligonucleotide primers, Amplicon size and corresponding annealing temperature are depicted in Table I.

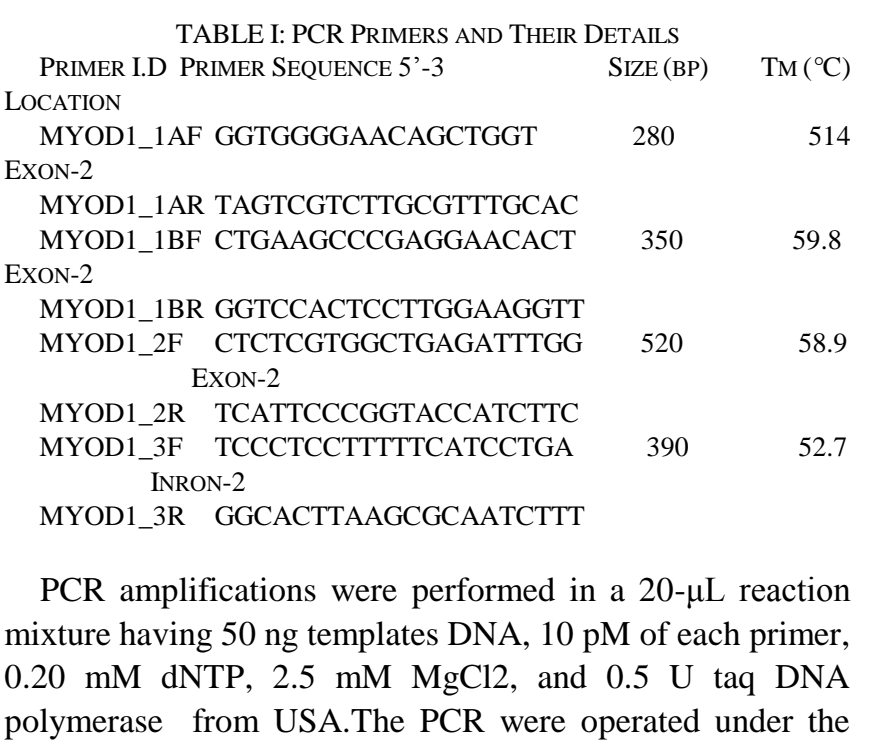

following conditions: initial denaturation at $95^{\circ} \mathrm{C}$ for $5 \mathrm{~min}$, 32 cycles of denaturation at $94^{\circ} \mathrm{C}$ for $30 \mathrm{~s}, 58^{\circ} \mathrm{C}$ annealing temperature for $30 \mathrm{~s}$, extension at $72^{\circ} \mathrm{C}$ for $30 \mathrm{~s}$, and a final extension at $72^{\circ} \mathrm{C}$ for $10 \mathrm{~min}$. Electrophoresis of PCR product was performed on $1.5 \%$ agarose gels (containing $200 \mathrm{ng} / \mathrm{mL}$ ethidium bromide) using $1 \times$ TBE buffer ( $89 \mathrm{mM}$ Tris, $89 \mathrm{mM}$ boric acid, $2 \mathrm{mM}$ Na2EDTA).

TABLE II: GENOTYPIC, ALLELIC FREQUENCIES AND POPULATION GENETIC INDICES AT BOVINE MYOD1 GENE LOCUS IN FIVE PAKISTANI INDIGENOUS

\begin{tabular}{|c|c|c|c|c|c|c|c|c|c|}
\hline \multicolumn{10}{|c|}{ CATTLE BREEDS } \\
\hline \multirow[t]{2}{*}{ Breeds } & \multicolumn{3}{|c|}{ Genotypic frequencies(N) } & \multicolumn{2}{|c|}{$\begin{array}{c}\text { Allelic } \\
\text { frequencies }\end{array}$} & \multirow{2}{*}{$\begin{array}{c}\text { Effective } \\
\text { allele } \\
\text { number } \\
\mathrm{Ne}\end{array}$} & \multirow[t]{2}{*}{ PIC } & \multirow[t]{2}{*}{$\mathrm{He}$} & \multirow[t]{2}{*}{$\begin{array}{c}\mathrm{X}^{2} \\
(\mathrm{HWE})\end{array}$} \\
\hline & $\mathrm{CC}$ & CG & GG & $\mathrm{C}$ & G & & & & \\
\hline RS & 0.2900 & 0.5100 & 0.2000 & 0.5450 & 0.4550 & 1. 9839 & 0.3730 & 0.4960 & 0.0008 \\
\hline TR & 0.3100 & 0.4600 & 0.2300 & 0.5400 & 0.4600 & 1. 9873 & 0.3734 & 0.4968 & 0.0055 \\
\hline SW & 0.5000 & 0.4500 & 0.0500 & 0.7250 & 0.2750 & 1.6632 & 0.3192 & 0.3988 & 0.0165 \\
\hline $\mathrm{BN}$ & 0.4500 & 0.4600 & 0.0900 & 0.6800 & 0.3200 & 1.7705 & 0.3405 & 0.4352 & 0.0032 \\
\hline $\mathrm{CL}$ & 0.4500 & 0.4600 & 0.0900 & 0.6800 & 0.3200 & 1. 7705 & 0.3405 & 0.4352 & 0.0032 \\
\hline
\end{tabular}

Here: Red Sindhi cattle (RS), Thari cattle (TR), Sahiwali cattle (SW), Bhagnari breed $(\mathrm{BN})$ and Cholistani breed $(\mathrm{Cl})$ and $\mathrm{N}=$ Number of observations.

TABLE III: LEAST SQUARE MEANS AND STANDARD ERRORS OF THE MEAT QUALITY TRAITS FOUND FOR THE GENOTYPES OF THE MYOD1 AT C.643G > T.LOCUS IN PAKISTANI CATTLE BREEDS

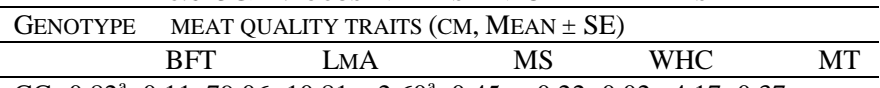

$\begin{array}{llllll}\text { CC } & 0.82^{\mathrm{a}} \pm 0.11 & 79.06 \pm 10.81 & 2.60^{\mathrm{a}} \pm 0.45 & 0.22 \pm 0.02 & 4.17 \pm 0.37\end{array}$

$\begin{array}{llllll}\text { CG } & 0.95^{\mathrm{b}} \pm 0.11 & 85.97 \pm 8.00 & 2.13^{\mathrm{ab}} \pm 0.85 & 0.22 \pm 0.05 & 4.12 \pm 0.48\end{array}$

GG $\quad 0.96^{\mathrm{b}} \pm 0.13 \quad 89.37 \pm 8.63 \quad 2.13^{\mathrm{b}} \pm 0.64 \quad 0.22 \pm 0.05 \quad 4.16 \pm 0.54$

P-VALUE $0.039 * \quad 0.073 \quad 0.038^{*} \quad 0.852 \quad 0.961$

Here; Back fat thickness (BFT)/cm; Loin muscle area (LMA)/cm2; Marbling score (MS)/1-5; Water holding capacity (WHC)/\%; Meat tenderness (MT)/kg.

The PCR products were purified with Wizard Prep PCR purification kit (USA made) and sequenced by ABI PRIZM 3730 DNA sequencer (Perkin-Elmer Shanghai Sangon Biological Engineering Technology, Ltd.). DNA polymorphisms were analyzed by comparing the obtained sequence data with the sequences in the NCBI database (http://www.ncbi.nlm.nih.gov) using MEGA software (version 5.2).

\section{PCR-SSCP Analyses}

Polymerase chain reaction was performed to amplify the template DNA sequence and then the PCR products were analyzed for screening the single-strand conformation polymorphisms (SSCP). Aliquots of $4 \mu \mathrm{L}$ of above PCR products were combined with $8 \mu \mathrm{L}$ of denaturing solution (95\% formamide, $25 \mathrm{mM}$ EDTA, $0.025 \%$ xylene-cyanole and $0.025 \%$ bromophenol blue), incubated at $98^{\circ} \mathrm{C}$ for $10 \mathrm{~min}$, and then chilled on ice. Denatured DNA were loaded onto $10 \%$ PAGE gel in $1 \times$ TBE buffer under a constant voltage of $120 \mathrm{~V}$ for $12 \mathrm{~h}$. Finally, the gel was stained with $0.1 \%$ silver nitrate and visualized and developed with $2 \% \mathrm{NaOH}$ solution (containing $0.1 \%$ formaldehyde), according to [15].

\section{PCR Purification and Sequencing}

The PCR products were purified with Wizard Prep PCR purification kit (USA made) and sequenced by ABI PRIZM 3730 DNA sequencer from KRL general laboratory (Dr.Abdul Qadeer Khan Laboratory) Islamabad, Pakistan. DNA polymorphisms were analyzed by comparing the obtained sequence data with the sequences in the NCBI 
database (http://www.ncbi.nlm.nih.gov) using MEGA software (version 5.2).

\section{E. Statistical Analyses}

Genotype and allelic frequencies of each of the above mentioned Chinese indigenous cattle breeds were calculated directly. The following items of population genetic indices, $\mathrm{He}$ (gene heterozygosity), Ho (gene homozygosity), $\mathrm{Ne}$ (effective allele numbers) and PIC (polymorphism information content), were determined according to [16] and [17]. The differences in genotypic frequencies of SNP were determined for deviations from Hardy-Weinberg equilibrium by mean values \pm S.E.M, which were performed by using statistical product and service solutions (SPSS version 17.0).

Whereas, the Association analyses between MyoD genotypes and meat quality traits of Sindhi cattle breeds were determined by the least square method (GLM procedure, SAS version 8.0). According to the procedure of liu [18], it was followed to calculate both additive and dominant effects by using REG method of the SAS version 8.0 (SAS institute 1999).Following model was applied to analyze the data:

$$
Y i j k l=\mu+S i+B j+G k+D 1+b i j k l X i j k l+e i j k l
$$

Here: Yijkl stands for observed value of meat quality traits, $\mu$ for the overall population mean. Si stands for the sex effect ( $i=1$ for male, 0 for female). $B j$ stands for the breed effect, $\mathrm{Gk}$ stands for the effect of the kth genotype, $D l$ denotes the effect of the first year. bijkl stands is the regression coefficient of the slaughter age, and finally eijkl is the random residual matching to the observed value.

\section{RESULTS}

\section{A. Genetic Polymorphism of Bovine MyoD-1 Gene and $X^{2}$} Test

MyoD-1 Exon-2 analysis showed that there was a c. $679 \mathrm{G}>\mathrm{A}$

Synonymous mutation at 643 - bp position (Fig. 1).The genetic diversity of the locus was determined (Table II and Table II). The results of the comparative genetic diversity predicts that GG genotype frequency ranges from Lowest in Cholistani cattle breed (0.0900) to highest in Thari cattle breed (0.230). Whereas, CC Genotype frequency ranges from lowest in Red Sindhi cattle (0.290) to highest in Sahiwali cattle breed (0.500). Finally, the heterozygous genotype frequency of the Sahiwali cattle breed was Lowest (0.450) and Red Sindhi cattle breed (0.510) was Highest. Furthermore, our results suggested that the polymorphism information Content (PIC) value of the all of the breeds observed was at medium level as per with the classification of the PIC value (Low Polymorphism if PIC value is $<0.25$, medium polymorphism if the PIC value is in between the $>0.25$ to $<0.5$ ) and high value of the polymorphism if the PIC value is $>0.5$ ). Therefore, in short we can say that the studies breeds polymorphism value is of medium level but the $X^{2}$ test value of the of the Sahiwali Cattle breed is highest and the same test also reveals that the genotypic distributions in all the cattle breeds involved agreed with Hardy-Weinberg Equilibrium $(P<0.05)$.

\section{B. Genetic Analysis of MyoD-1 Gene and SNP Marker Association}

Marker assisted study of the MyoD-1 gene at exon-2 locus shows the point mutation, which leads to the change of Nucleotide (c.643G>T) and as result of this change in Nucleotide, the Codon changed (GGC>TGC) and ultimately it yields the changed translation product (amino acid p.Gly215Cys). Furthermore, our results of the Least Square Analysis for the novel mutation c.679G $>A$ is significantly associated $(P>0.05)$ with Back fat thickness (BFT) and Marbling (MB) but did not show a significant association with other traits such as Eye muscle area (EMA), Water holding Capacity (WHC), and meat tenderness (MT).

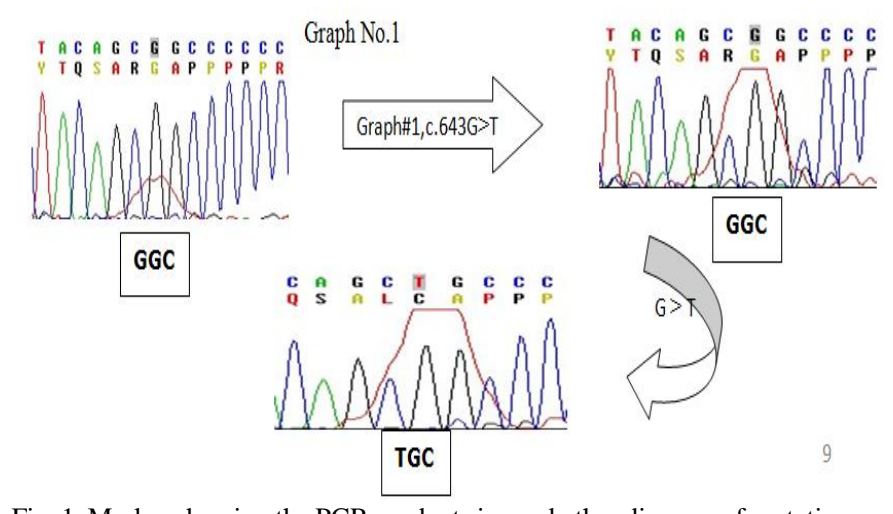

Fig. 1. Marker showing the PCR product size and other diagram of mutation.

\section{CONCLUSION}

Many factors affect the quality of meat, including the way animals are fed, managed, slaughtered as well as both carcass handling and processing post-slaughter. While there is often emphasis on the management systems that can be implemented to meet market specifications there has, until recent years, been little emphasis on factoring in the molecular or biological components of meat quality. Since last few decades, advancement in molecular genetics has led to the identification of multiple genes or genetic markers associated with genes that affect traits of interest in livestock animals, including single genes of large effect and quantitative trait loci (QTL; genomic regions that affect quantitative traits). Intrinsic quality of beef, especially its tenderness, depends on post-mortem factors associated with meat ageing and muscle characteristics of live animals, which themselves depend on genetic and environmental factors. By the help of functional genomics approach to understanding the molecular basis of meat quality, we can gain further insight into the complex interplay of gene expression events involved in the development of meat quality. At present, genome projects have advanced our understanding of gene expression and helped elucidate the function of large portions of the genome.

The associations between single nucleotide polymorphisms of MYOD1 and meat quality traits were studied in commercial lines of Pakistani indigenous cattle breeds such as Red Sindhi breed, Thari breed, Malari breed, Bhagnari breed, and The results of the Allelic frequencies and Polymorphism Information Content showed a medium diversity. Herewith, the $X^{2}$ test value of the Sahiwali Cattle breed is highest and the 
same test also reveals that the genotypic distributions in all the cattle breeds involved agreed with Hardy-Weinberg Equilibrium $(P<0.05)$.

Least Square analysis for the marker assisted analysis study shows that the observed novel mutation c.679G $>A$ is significantly associated $(P>0.05)$ with Back fat thickness (BFT) and Marbling (MB) but did not show a significant association with other traits such as Eye muscle area (EMA), Water holding Capacity (WHC), and meat tenderness (MT). Animal Geneticians and breeders consider both of these traits as the key traits of determining the meat quality in animals. This research will be helpful to furthermore improve the meat quality in Pakistani cattle breeds by using the marker assisted technology.

\section{ACKNOWLEDGMENT}

We are pleased to acknowledge Dr. Abdul Hameed Principal Scientific Officer and Associate Professor, Institute of Biomedical and Genetic Engineering (IBGE), 24-Mauve Area, G-9/1, Islamabad, Pakistan. The honorable Higher Education Commission (HEC), Pakistan for providing the finding of the research project No: PM-IPFP/HRD/HEC/2012/3560

\section{REFERENCES}

[1] K. Rosenvold and H. J. Andersen, "Factors of significanceforpork quality - A reviewm," Meat Science, vol. 64, no. 3, pp. 219-237, 2003.

[2] L. Andersson, "Genetic dissection of phenotypic diversity in farm animals," Nature reviews. Genetics, vol. 2, no. 2, pp. 130-138, 2001.

[3] J. L. Noguera et al., "Estrogen receptor polymorphism in Landrace pigs and its association with litter size performance," Livest Prod Sci., vol. 82, pp. 53-59, 2003.

[4] A. H. Visscher, "The family and meat production - A review. In: Proc. 40th Inter," Congress of Meat Sci. Technology, Hague, Netherlands, 1994.

[5] F. J. Verburg et al., "Influences of myogenin genotypes on birth weight, growth rate, carcass weight, backfat thickness, and lean weight of pigs," J. Anim. Sci., vol. 77, pp. 2352-2356, 1999.

[6] D. Pette and S. Staronr, "Mammalian skeletal muscle fiber type transitions. Internat," Rev. Cyt., vol. 170, pp. 143-223, 1997.

[7] A. V. Pires et al., "Association of MYF5 gene allelic variants with production traits in pigs," Genet Mol Biol., vol. 28, pp. 363-369, 2005.

[8] M. F. W. T. Pas, M. E. Everts, and H. P. Haagsman, "Muscle development of livestock animals: physiology, genetics and meat quality," 2004, CABI, 0851998119.

[9] D. Cies'lak, W. Kapelan'ski, T. Blicharski, and M. Pierzchała, "Restriction fragment length polymorphisms in myogenin and myf3 genes and their influence on lean meat content in pigs," J. Anim Breed Genet, vol. 117, no. 1, pp. 43-55, 2000.

[10] J. Pierzchala et al., "Polymorphisms in coding and regulatory regions of the porcine MYF6 and MYOG genes and expression of the MYF6 gene in longissimus dorsi versus production traits in pigs," J. Appl. Genet., vol. 47, pp. 131-138, 2006.

[11] J. Verner et al., "Impact of MYOD family genes on pork traits in Large White and Landrace pigs," J. Anim. Breed. Genet., vol. 124, pp. 81-85, 2007.

[12] P. Humpolíček, T. Urban, and Z. Tvrdoň, "Relation of porcinemyogenin gene PCR/RFLP MspI and reproduction traits of the Czech Large White sows," Livestock Sci., vol. 110, pp. 288-291, 2007.

[13] M. S. A. Bhuiyan, "Identification of SNPs in MYOD gene family and with carcass traits in cattle," Sci, doi:10.1016/j.livsci.2009.05.019, 2009 .

[14] J. Sambrook and D. W. Russell, "Translated by Huang," Molecular Cloning A Laboratory Manual, 3rd., Beijing, China: Sci. Press, 2002.

[15] C. L. Zhang, Y. Wang, H. Chen, X. Y. Lan et al., "Enhance the efficiency of single-strand conformation polymorphism analysis by short polyacrylamide gel and modified silver staining," Anal. Biochem., vol. 365, pp. 286-287, 2007.

[16] M. Nei and A. K. Roychoudhury, "Sampling variance of heterozygosity and genetic distance," Genetics, vol. 76, pp. 379-390, 1974.

[17] M. Nei and W. H. Li, "Mathematic model for studying genetic variation in terms of restriction endonucleaes," PNAS, vol. 76, pp. 5269-5273, 1979, U.S.A.

[18] Z. J. Liu and R. Dunham, "Genetic linkage and QTL Mapping of ictalurid catfish,” Circ. Bull., vol. 321, pp. 1-19, Alabama Agricultural Experiment Station, USA, 1998.

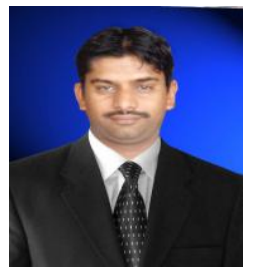

Javed Ahmed Ujan was born on September 18, 1985 in village Ali Bakhsh Ujan, Tehsil Gambat, District Khairpur miras Sindh province of Islamic Republic of Pakistan. He completed his under graduation (bachelor's degree /B.Sc) in the field of microbiology from Shah Abdul latif University, Khairpur miras, Sindh, Pakistan during the session 2002-2004 and took his graduation ( master's degree /MSc) in the field of biology/animal sciences from Quaid-I-Azam University, Islamabad, Pakistan during the session 2005-2007). After completion of master's degree, he appeared for international subjective graduation examination, which was conducted by national testing service (NTS) Pakistan. He was also successively qualified for the provincial merit criteria in Pakistan and Chinese Scholarship counsel (CSC). Thereafter, he was sent to China for the degree of doctors of philosophy $(\mathrm{PhD})$ under the Cultural Exchange Scholarship Program jointly supported by Ministry of Education, Government of Pakistan and Ministry of Education, Government of China.

Mr. Ahmed joined Northwest A \&F University, Yangling, China for the period of four years (2008-2012) under supervision of Prof. Dr. Zan linsen in the Animal Genetics \& Breeding group. In addition, Mr. Ujan also has two international Abstracts from his PhD research work. Whereas, one more SCI paper having impact factor 2 is also accepted for publication and some other papers are in pipeline that will published soon.

Besides this, he is also the author of 6 more Chinese articles given as under. Recently, Mr Javed Ahmed Ujan has been appointed on the post of assistant professor by Higher Education Commission (HEC) of Pakistan in the department of Zoology at Shah Abdul latif University, Khairpur, Pakistan. 